\title{
Detection and quantification of Flavobacterium psychrophilum in water and fish tissue samples by quantitative real time PCR
}

Nicole Strepparava ${ }^{1,2^{*}}$, Thomas Wahli ${ }^{2}$, Helmut Segner ${ }^{2}$ and Orlando Petrini ${ }^{3}$

\begin{abstract}
Background: Flavobacterium psychrophilum is the agent of Bacterial Cold Water Disease and Rainbow Trout Fry Syndrome, two diseases leading to high mortality. Pathogen detection is mainly carried out using cultures and more rapid and sensitive methods are needed.

Results: We describe a qPCR technique based on the single copy gene $\beta^{\prime}$ DNA-dependent RNA polymerase (rpoC). Its detection limit was 20 gene copies and the quantification limit $10^{3}$ gene copies per reaction. Tests on spiked spleens with known concentrations of $F$. psychrophilum ( $10^{6}$ to $10^{1}$ cells per reaction) showed no cross-reactions between the spleen tissue and the primers and probe. Screening of water samples and spleens from symptomless and infected fishes indicated that the pathogen was already present before the outbreaks, but F. psychrophilum was only quantifiable in spleens from diseased fishes.

Conclusions: This qPCR can be used as a highly sensitive and specific method to detect $F$. psychrophilum in different sample types without the need for culturing. QPCR allows a reliable detection and quantification of F. psychrophilum in samples with low pathogen densities. Quantitative data on F. psychrophilum abundance could be useful to investigate risk factors linked to infections and also as early warning system prior to potential devastating outbreak.
\end{abstract}

\section{Background}

Flavobacteria are non-fermentative, catalase and oxidase positive, gram negative, yellow rods frequently isolated from different ecosystems [1-3]. Some species, in particular Flavobacterium branchiophilum, F. columnare and F. psychrophilum are feared fish pathogens responsible for disease outbreaks in fish farms worldwide [4-9]. F. psychrophilum cause either skin, gills and fin lesions as well as systemic disease in internal fish organs, the so called Bacterial Cold Water disease (BCW) and Rainbow Trout Fry Syndrome (RTFS), which can both lead to high mortality in the populations affected $[4,10]$.

Diagnosis of F. psychrophilum infections relies mainly on macroscopic symptoms, microscopic examination of fresh samples of fish spleens, and cultures of samples from tissues on non-selective agar medium [11-14]. Due

\footnotetext{
* Correspondence: nicole.strepparava@bluewin.ch

'Laboratory of Applied Microbiology, University of Applied Sciences and Arts of Southern Switzerland, Via Mirasole 22a, 6500 Bellinzona, Switzerland ${ }^{2}$ Centre for Fish and Wildlife Health, University of Bern, Länggassstrasse 122, 3001 Bern, Switzerland

Full list of author information is available at the end of the article
}

to the often only superficial location of the disease on the fish as well as low densities and slow growth of the pathogen, early stages of infection are easily overlooked. This can lead to false negative results, thus increasing the number of incorrect diagnoses [15].

Fluorescent in situ hybridization (FISH) has recently been described to diagnose $F$. psychrophilum infections in fish: the method is fast, reliable, and allows detection of $F$. psychrophilum concentrations of $>10^{5}$ cells $/ \mathrm{ml}$ in water and spleen samples [16]. In some cases FISH provide quantitative results [17], but this $F$. psychrophilum specific FISH, allows only a qualitative detection but no quantification of the pathogen [16].

In the past few years, PCR methods have been described to detect and diagnose F. psychrophilum infections $[18,19]$. PCR, as well as nested PCR, are highly sensitive, fast, and could allow simultaneous detection of different pathogens $[20,21]$. Currently available PCR techniques can be used to detect $F$. psychrophilum in a sample $[18,19]$.

\section{Biomed Central}

(c) 2014 Strepparava et al.; licensee BioMed Central Ltd. This is an Open Access article distributed under the terms of the Creative Commons Attribution License (http://creativecommons.org/licenses/by/2.0), which permits unrestricted use, distribution, and reproduction in any medium, provided the original work is properly credited. 
Real time quantitative PCR (qPCR) has been used in several studies to improve sensitivity of methods of detection and quantification of bacteria [22]. Due to its high sensitivity, this technique has widely been used to discover low amounts of pathogen DNA in the environment or in an organism during infection, to monitor its spread as well as to study healthy carriers as pathogen reservoirs [22-24]. Recently two qPCR for F. psychrophilum were developed $[25,26]$ both however were tested only on fish tissues and there is still the need for quantitative methods allowing quantification of $F$. psychrophilum in field samples such as water and soil.

The choice of a species-specific marker gene is crucial for a good diagnostic PCR. rpoC, a single copy gene present in Flavobacterium spp., has been used to assess phylogenetic relationships and mutation rates in different genera and species and has been shown to be more variable at the interspecific level than the 16S rRNA gene [27-29]. Moreover, each bacterial cell may contain a variable number of $16 \mathrm{~S}$ rRNA genes copies. For instance, $F$. psychrophilum harbors on average $616 \mathrm{~S}$ rRNA genes copies, thus making it difficult to precisely quantify the number of bacteria in a sample $[26,30]$. Therefore, targeting single copy genes allows a straightforward and more accurate quantification of the pathogen, with one gene copy corresponding to one bacterial cell [31]. In addition, $r p o C$ variability could provide specific amplification of the $F$. psychrophilum target sequence, making rpoC a good candidate for use in qPCR.

Therefore, the aim of this study was to develop a qPCR using the rpoC gene as a target to rapidly detect and quantify $F$. psychrophilum in the natural environment.

\section{Results}

All F. psychrophilum (100 isolates) were correctly detected with the primers used while all other 130 strains were not amplified (Table 1). The specific primers used in this study showed excellent specificity, sensitivity, and positive and negative predicted values (all 100\%).

\section{qPCR standards and spiked spleens}

All qPCR standards and sample runs met the reliability criteria defined in the methods. We observed a good correlation between cycle threshold $(\mathrm{Ct})$ values and quantifications of standards, with the slope of the linear regression curve over a $7-\log$ range from $2 \times 10^{7}$ to $2 \times 10^{0}$ rpoC gene copies being $-3.18\left(\mathrm{R}^{2}=0.998\right)$, indicating an efficiency of 106\% (Figure 1). Purified, amplified fragment dilutions were therefore used for all successive quantifications as standards. The limit of detection (LOD) was 20 gene copies per reaction (LOD 100\%). It was possible to amplify $2 \mathrm{~F}$. psychrophilum rpoC gene copies per reaction in $90 \%$ of cases. This value is lower than the theoretical value reported by Bustin et al. [32], who concluded that the most sensitive LOD theoretically possible would be 3
Table 1 Bacteria used to test specificity and sensitivity of F. psychrophilum specific rpoC primers

\begin{tabular}{lll}
\hline Taxon & $\begin{array}{l}\text { No. of isolates } \\
\text { investigated }\end{array}$ & Origin \\
\hline $\begin{array}{l}\text { Flavobacterium } \\
\text { branchiophilum }\end{array}$ & 1 & (France) \\
F. aquatile & 1 & (France) \\
F. aquidurense & 1 & DSM18293 \\
F. columnare & 2 & (France) (USA) \\
F. frigidimaris & 1 & (France) \\
F. frixellicola & 1 & (France) \\
F. hercynium & 1 & DSM18292 \\
F. hydatis & 1 & DSM2063 \\
F. johnsoniae & 1 & (France) \\
F. limicola & 1 & DSM15094 \\
F. pectinovorum & 1 & DSM6368 \\
F. psychrolimnae & 1 & (France) \\
F. psychrophilum & 100 & DSM3660 and isolates \\
& & from BTF, BTL and RT \\
F. succinicans & 1 & DSM4002 \\
Flavobacterium spp. & 88 & Water, tank swab and fish \\
Chryseobacterium spp. & 17 & isolates from BTF and RT \\
Other Aquatic Bacteria & 11 & Water and tank swabs \\
& & Water, swab and fish isolates \\
from BTF BTL and RT
\end{tabular}

$R T$ rainbow trout, $B T F$ brown trout fario; $B T L$ brown trout lacustris.

copies per reaction, with a $95 \%$ chance of including at least 1 gene copy. The quantification limit (QL) was $10^{3}$ gene copies per reaction (QL 96\%). This comparatively high value can be explained by losses during the DNA extraction procedure in samples with low bacteria concentrations.

qPCR showed a weak cross-reaction with the highest $F$. branchiophilum and F. johnsoniae pure DNA concentrations (respectively $10^{6}$ cells and $10^{7}$ cells per reaction, with a mean of 50 and 100 copies detected). This values, however, showed standard deviations $>25 \%$ and were thus to be considered as negative according to the reliability check rules we adopted. To investigate cross-reaction with other DNA from fish pathogenic flavobacteria, qPCR was tested on mixtures of $F$. psychrophilum and $F$. columnare or F. branchiophilum DNA. Our qPCR showed a high specificity for F. psychrophilum and the agreement between observed and expected values of mixed samples was very good even at low copy numbers of the $F$. psychrophilum rpoC gene (Figure 2).

F. psychrophilum could be reliably detected also in spiked spleens (linear results down to 20 cells per reaction, $R^{2}=0.9991$ ). Quantification was reproducible without any observed interaction between spleen tissue DNA and the qPCR probe and primers (Figure 3). 


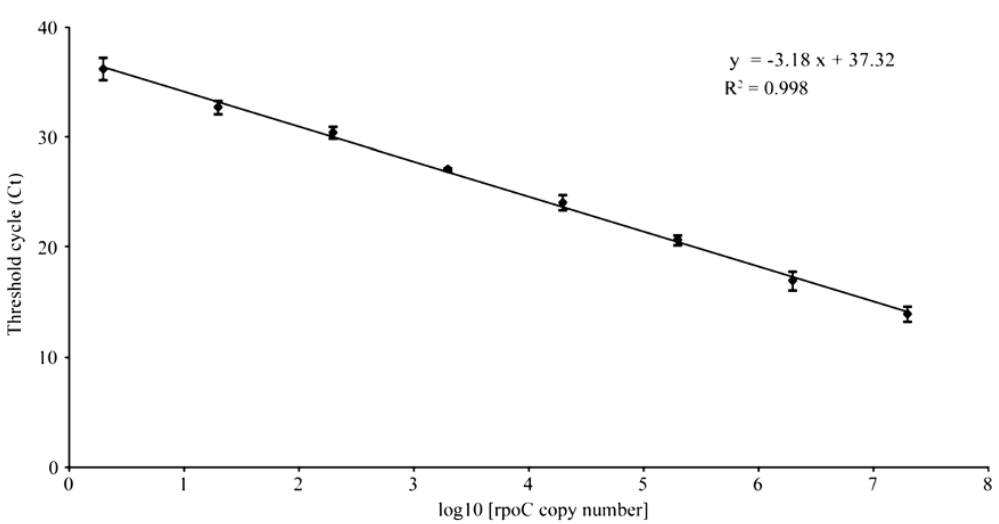

Figure 1 Calibration of standards. Each cycle threshold (Ct value) point corresponds to the mean of the 20 standards (each measured in triplicate) of samples. Regression coefficients for the 20 standards plotted: slope -3.18 , intercept $+37,32, R^{2}: 0.998$.

\section{Detection and quantification of F. psychrophilum in environmental samples}

No F. psychrophilum could be detected in any of the water samples by culture or FISH.

F. psychrophilum, however, could be discovered by qPCR in $7 \%$ of the inlet water samples and $53 \%$ of the tank water samples (LOD $\geq 20$ copies, i.e. 66 F. psychrophilum cells/ $\mathrm{ml}$ sampled) in a subset of 60 inlets and 60 water tanks samples from fish farms reporting at least one F. psychrophilum outbreak in 2009; a positive inlet was correlated with positive tank samples $(n=4)$ while no correspondence was observed in 29 farms, which had throughout positive tank water samples ( $\min$ and max values: from 42 to 3,200 cells $/ \mathrm{ml}$ ) but negative inlet water. Values over the QL (3,300 F. psychrophilum cells/ml sampled) were observed only in 1 pair of inlet and tank water samples with values of $1.5 \times 10^{4} \pm 352$ and $3.5 \times 10^{4} \pm 724$ cells/ml (Table 2). Due to the comparatively high number of tank water samples testing positive for $F$. psychrophilum observed in the first subset of samples examined, we decided to screen all 2010 tank samples. Of the 85 tank water samples collected in 2010, however, only 8 (10\%) were positive (range: 43 to 3,000 cells $/ \mathrm{ml}$ ) (Table 2).

In contrast to culture or FISH, F. psychrophilum was detected in healthy and quantified in infected fish by qPCR. F. psychrophilum densities in healthy individuals were well below the QL, in a range of 0 to 15,000 cells per spleen, whereas spleens from diseased fish contained bacterial densities over the $\mathrm{QL}$, in a range of 7,000 to $7.7 \times 10^{8}$ cells per spleen. Positive results by qPCR were reported for all spleens originating from the 4 outbreaks; FISH allowed detecting F. psychrophilum in all outbreaks while culture showed F. psychrophilum only in 3 outbreaks.

\section{Risk factors}

We could not show any clear correlation between the presence of $F$. psychrophilum and the environmental parameters measured. We observed that the F. psychrophilum densities tended to increase and to cause outbreaks after changes in water parameters. For instance, a change in more than one ecological parameter tended to correlate with an outbreak or at least an increase of the number of

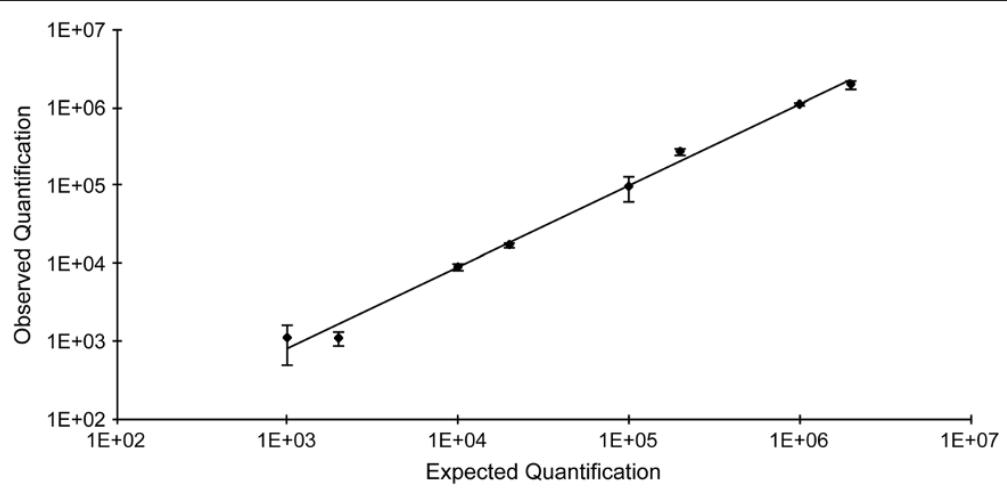

Figure 2 Expected and observed F. psychrophilum cells. Cell number detected in a mixture with F. columnare $\left(10^{7}, 10^{4}, 10^{3}\right.$ and $10^{2}$ cells per reaction) and $F$. branchiophilum (number of bacteria $10^{6}, 10^{4}, 10^{3}$ and $10^{2}$ cells per reaction). Slope: $1.0156, R^{2}=0.9961$. 


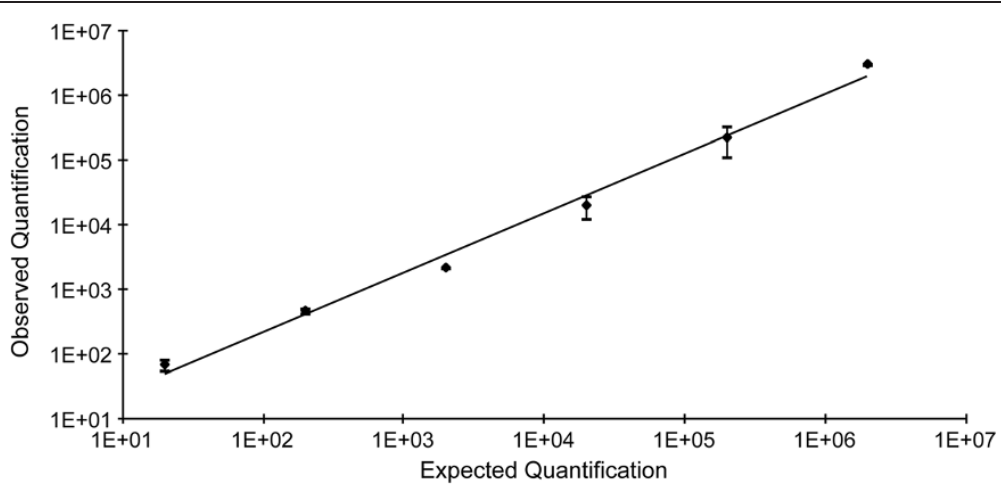

Figure 3 Expected and observed F. psychrophilum cells in spiked spleens. Concentrations of 5 F. psychrophilum isolates (from $2 \times 10^{1}$ to $2 \times 10^{6}$ cells per reaction), slope: 1.5678 and $R^{2}=0.9991$.

F. psychrophilum in water (Figure 4). This observation, however, cannot be supported by any statistical analysis, because too few outbreaks could be analyzed during the study period.

\section{Discussion}

This study shows that the qPCR assay developed is very sensitive and able to detect and quantify F. psychrophilum in water samples and fish spleens with no amplification of the other 130 non-target bacterial isolates.

In the water samples investigated, LOD was 20 rpoC gene copies per reaction and QL $10^{3}$ cells per reaction. The quantification limit was quite high: possibly random losses happened because of DNA uptake in columns during extraction of low cell concentrations. As DNA extraction from samples containing $<1000$ cells/ $\mu$ l was probably low, the quantification by qPCR was also not reliable. In a $16 \mathrm{~S}$ rRNA gene $F$. psychrophilum qPCR recently described, quantification was based on the assumption that all isolates of $F$. psychrophilum have 6 repetitions of the 16S rRNA gene present in their genome [26]. This qPCR, however, needs to be adjusted for the number of $16 \mathrm{~S}$ rRNA genes. It also showed to be less reliable by amplifying non-target DNA after $\sim 30$ cycles, while a qPCR based on the rpoC gene supplies direct quantification and is more reliable at low bacterial DNA concentrations. The rpoC gene is present in all Flavobacterium genomes so far investigated [30,33-36] and has already been used to identify clusters of species and species relatedness in taxonomy instead of $16 \mathrm{~s}$ rRNA [27,29]. While the $16 \mathrm{~S}$ rRNA qPCR is doubtless more sensitive (down to 9 gene copies), we expect our qPCR to be more specific for F. psychrophilum. While we were developing and testing our qPCR, Marancik and Wiens [25] were developing a single copy gene PCR based on a sequence coding for a conserved $F$. psychrophilum protein with unknown function. They reported the limit of detection of their method to be 3.1 genome units per reaction, while for our qPCR it is approximately 20 . On the other hand, their quantification limit in the spleen was approximately 500 bacteria in $1.5 \mu \mathrm{l}$ of a $200 \mu \mathrm{l}$ DNA elution, while our limit was 20 bacteria in $2 \mu \mathrm{l}$ of reaction mixture. In addition, while Marancik and Wiens [35] tested their qPCR only against a limited number of non-target organisms and only under laboratory conditions, we challenged our qPCR against strains of different fish pathogens and of bacterial genera normally present in water. In addition, we tried to carry out our testing under conditions reflecting a real-life situation where bacterial species (including other fish pathogens) and substances (antibiotics, minerals, humic acids) are normally present and can interfere with the target organism detection and quantification. Overall, however, we would expect Marancik \& Wiens' and our methods to be roughly comparable, although our quantification limits in

Table 2 Origin and percent of samples positive to $F$. psychrophilum

\begin{tabular}{|c|c|c|c|c|c|}
\hline & Origin & No. of samples & $\begin{array}{l}\text { \% Positive for } \\
\text { F. psychrophilum }\end{array}$ & $\begin{array}{l}\text { \% of samples } \\
\text { quantified }\end{array}$ & Cells/ml \\
\hline \multicolumn{6}{|l|}{ Inlet and tank 2009} \\
\hline Inlets & Ticino fish farms & 60 & $7 \%$ & $1.6 \%$ & 73 to $1.5 \times 10^{4}$ \\
\hline Tanks & Ticino fish farms & 60 & $53 \%$ & $1.6 \%$ & 42 to $3.5 \times 10^{4}$ \\
\hline \multicolumn{6}{|l|}{2010} \\
\hline Tanks & Swiss fish farms & 85 & $10 \%$ & $0 \%$ & 43 to $3^{\prime} 000$ \\
\hline Healthy carriers 2011, 2012 & Swiss fish farms & 43 & $80 \%$ & $0 \%$ & $0-400$ \\
\hline
\end{tabular}




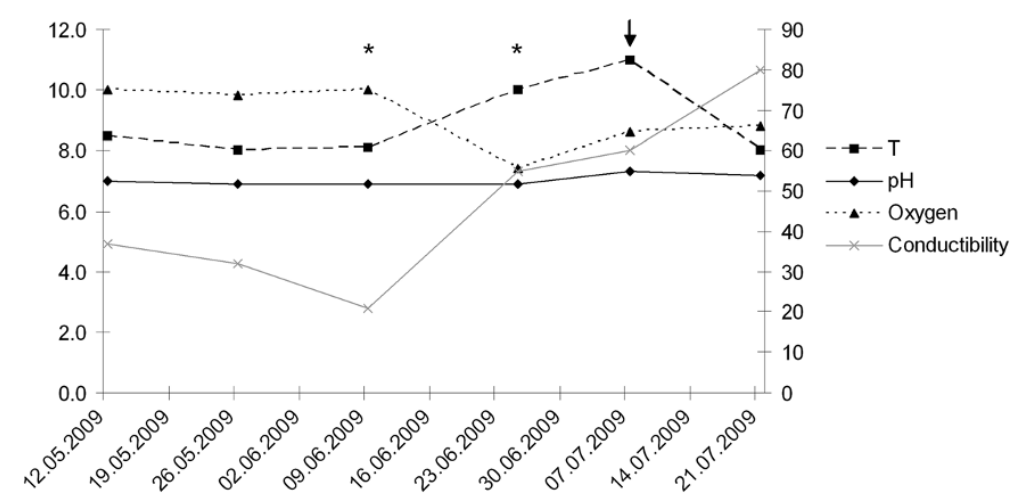

Figure 4 Seasonal variation example. Physicochemical parameters [primary y axis: temperature $\left(\mathrm{T}\right.$ in $\left.{ }^{\circ} \mathrm{C}\right), \mathrm{pH}$ of water, oxygen concentration ( $\mathrm{mg} / \mathrm{L})$; secondary y axis: conductibility ( $\mu$ Siemens)] measured in a selected fish farm (Ticino, Switzerland) during 2009. Detection of the pathogen in the tank water samples started on 9 June $2009\left(^{*}\right)$, the arrows indicate a flavobacteriosis outbreak in brown trout fario.

the spleen is better and we were able to demonstrate the applicability of our technique also on water samples from fish farms.

Cross-reactions with other species belonging to the same genus were not observed in in silico testing of primers against the entire genome of $F$. branchiophilum, $F$. columnare, $F$. indicum and $F$. johnsoniae. When the qPCR was used on mixed samples of $F$. psychrophilum with F. columnare and F. branchiophilum no cross-reaction was observed. In addition, quantification in spiked spleens gave linear results down to a concentration of 20 bacteria per reaction. In our study we used rather low concentrations of bacteria to spike spleen tissues $\left(10^{2}\right.$ cells/mg), as opposed to other studies in which higher bacterial loads were used. We thus conclude that the qPCR presented here is highly specific for the target organism.

F. psychrophilum seem to be present only in few samples at detectable values, tanks being more often colonized than inlet waters. $53 \%$ and $10 \%$ of tank water samples collected in the fish farms respectively during the years 2009 and 2010 were positive for $F$. psychrophilum by qPCR. Data seem thus to suggest a high prevalence of the pathogen in 2009, with a regression in 2010, but this is most likely a consequence of the different sampling strategies adopted in the two seasons. In 2009, in fact, we screened only fish farms in Ticino where outbreaks of F. psychrophilum occurred, whereas in 2010 all Swiss fish farms under investigation were screened independently of any outbreaks diagnosis. We also used only $15 \mathrm{ml}$ water samples, whereas increasing the sample volume may also increase the probability to detect $F$. psychrophilum in environmental water samples. In addition, this was only a preliminary study to test the technique and its limits in natural field conditions: the study was neither planned nor powered to allow drawing any conclusions or making any interpretations about the disease distribution.
Unfortunately little is known about the pathogen in its environment and about its mode of transmission. We suggest that $F$. psychrophilum could be present and replicate in the tank (in both, fish and organic layer) and diffuse in the water [37], where favourable ecological conditions would allow colonization/infection of other fishes.

F. psychrophilum detection by $\mathrm{qPCR}$ in the spleen of diseased and symptomless fishes suggests that the pathogen may have already been present in the spleen of symptomless fish at densities below QL but above LOD. Marancik and Wiens [25] report similar results using their qPCR, which detected the presence of F. psychrophilum in few symptomless carriers that had been infected with the pathogen. In contrast, no infection was recorded prior to sampling of healthy-looking fishes in our study. Thus, F. psychrophilum is apparently able to colonize and live asymptomatically in the spleen, where it is inactive until favorable environment conditions and a weakening of the fish immune system allow this opportunistic pathogen to multiply, spread in the fish and eventually in the whole fish population. During outbreaks, fish spleen harbored higher amounts of the pathogen, at concentrations markedly higher than the QL. Healthy, colonized fish may thus act as reservoirs for infection: in our opinion, this is a valid assumption, because another study has demonstrated the presence of this pathogen in eggs and ovarian fluids [38]. Further investigations, however, are needed to assess the mode of transmission and ecology of this species.

qPCR detected and quantified F. psychrophilum in all $4 \mathrm{~F}$. psychrophilum outbreaks investigated in this study; 13 of 15 qPCR values were higher than LOD, and in 8 cases higher than the QL. FISH could also detect all outbreaks, while culture methods could detect only 3 outbreaks and one was incorrectly recorded as negative. 
Changes in water temperature (e.g. a temperature variation of $4^{\circ} \mathrm{C}$ ), oxygen availability in water, $\mathrm{pH}$ and conductibility could lead to a disease outbreak. In our study, changes in two or more parameters seemed to correlate with the detection of F. psychrophilum in the water. Factors that decrease host immune response are often crucial for the establishment of an infection by opportunistic pathogens $[39,40]$. Seasonality, for instance, was found to impact the Rainbow trout immune system due to pathogen density being lower in winter than in summer. Moreover, differences between winter and summer water temperatures may significantly change red blood cells counts in fish [41]. Different studies suggest also population densities in tanks as a potential risk factor [42-45]. Karvoven et al. [43] reported a positive correlation between temperature and onset of $F$. columnare infections, while a negative correlation was found between the presence of the flagellate Ichthyobodo necator, the causal agent of costiasis, and temperature. I. necator was also isolated from fish infected by F. psychrophilum [46]. Unfortunately, our observations on potential risk factors are restricted to four documented outbreaks only. It is therefore not possible to carry out any statistical analysis to describe potential interactions between factors and to quantify the importance of each factor for the establishment of the infection.

\section{Conclusions}

This study has shown that qPCR using the rpoC gene could be used as a reliable, specific diagnostic tool to detect and quantify F. psychrophilum colonisations and infections. This technique could be used to screen for the presence of the pathogen in fish farms in order to prevent devastating outbreaks. qPCR could also be applied in investigations of vertical pathogen transmission [15,38], to perform studies of risk factors including different stress conditions, and to check for outbreaks due to network structures among fish farms [47]. The symptomless presence of $F$. psychrophilum we have observed in some fish samples indicates that the survival of the pathogen may contribute to a significant risk for outbreaks caused by fish trade, with healthy carriers coming into contact with other individuals from different origins.

\section{Methods}

\section{Sampling strategy}

Water samples were collected in 2009 and in 2010 from the inlets and fish tanks of 22 independent Swiss fish farms. Inlet water flew directly from the river into separate tanks; the water volume ranged from 2 to $105 \mathrm{~m}^{3}$. The water flow was continuous. The detailed sampling structure is described in Table 2.

During 2009, water and different fish species were sampled every second week in 4 fish farms located in the Ticino Canton (Switzerland) (60 sampling actions).
In 2010, sampling was carried out in 22 fish farms all over Switzerland at 3 different periods (85 sampling actions). The first was in winter shortly before fishes started hatching (only water), the second was carried out 6 and the third 12 weeks after hatching and when fishes started feeding. At each sampling date six fishes [Rainbow trout (Oncorhinchus mykiss) and brown trout (Salmo trutta fario and Salmo trutta lacustris)] were collected concomitantly with two water samples, one from the inlet and one from the tank. $50 \mathrm{ml}$ of water were collected in $50 \mathrm{ml}$ Falcon tubes (Becton Dickinson BD, Switzerland), while fishes were collected in a container with water and brought back to the laboratory within $24 \mathrm{~h}$ after collection in refrigerating bags. Plating and fixation of water samples were carried out immediately upon arrival in the laboratory.

Population density of fishes in the tanks, physical (temperature, water conductibility, oxygen saturation, water volume) and chemical (disinfectant and antibiotic use) water parameters were recorded directly at the fish farm.

In the laboratory, $100 \mu \mathrm{l}$ of water collected were plated on Cytophaga enriched Agar Medium (CAM, medium 1133 DSMZ: $0.2 \%$ tryptone, $0.05 \%$ beef extract, $0.05 \%$ yeast extract, $0.02 \%$ sodium acetate, $1.5 \%$ agar). All plates were incubated at $15^{\circ} \mathrm{C}$ during 5 to 10 days. Yellow colonies (i.e. putative flavobacteria) were transferred onto fresh plates and screened with a Flavobacterium spp. and F. psychrophilum specific FISH [16]. Pure cultures of Flavobacterium spp. and F. psychrophilum were conserved at $-80^{\circ} \mathrm{C}$ in $1 \mathrm{ml}$ skimmed milk (Becton Dickinson, Switzerland) supplemented with $10 \%$ bovine serum and $20 \%$ glycerol.

Fixation of water samples was carried out according to Tonolla et al. [48] with the following modifications: $15 \mathrm{ml}$ of each water sample were filtered with a Millipore filtration system (Merck Millipore) with $3.0 \mu \mathrm{m}$ mesh size filters overlaid with $0.2 \mu \mathrm{m}$ mesh size filters. Each sample was covered with 4\% Paraformaldehyde Fixation Buffer (PBS: $0.13 \mathrm{M} \mathrm{NaCl}, 7 \mathrm{mM} \mathrm{Na} 2-\mathrm{HPO}_{4}, 3 \mathrm{mM} \mathrm{NaH} \mathrm{PO}_{4}, \mathrm{pH}$ 7.2) for $30 \mathrm{~min}$ and then washed twice with $1 \times$ Phosphate Buffered Saline (PBS). The overlay filters were transferred into plastic bags; $600 \mu \mathrm{l}$ of a $50 \%$ PBS-ethanol solution were added, the bags sealed and bacteria re-suspended by slightly rubbing the filter between thumb and forefinger. The suspension was then transferred into a $1.5 \mathrm{ml}$ Eppendorf tube and stored at $-20^{\circ} \mathrm{C}$ until DNA extraction. The DNeasy Blood \& Tissue Kit (QIAGEN - Switzerland) was used for DNA extraction of all fixed water samples.

For pathogen detection in animals, fish collected were killed by immersion in $0.01 \%$ benzocaine followed by section of the vertebral column. Spleen of rainbow trout, brown trout fario and brown trout lacustris were homogenized separately in $200 \mu \mathrm{l}$ of sterile water. $190 \mu \mathrm{l}$ of the homogenates were plated on CAM medium and incubated at $15^{\circ} \mathrm{C}$ for 5 to 10 days while the remaining $10 \mu \mathrm{l}$ were used for FISH [16]. 
Approval for animal experiments and water collection was obtained from the Federal Veterinary Office (FVO, Switzerland) and the Ticino Cantonal Veterinary Office (Authorization 03/2010 and 04/2010).

\section{Identification of colonies and diagnosis of outbreaks by FISH}

Identification of flavobacteria in general and F. psychrophilum in particular was carried out using a published FISH protocol [16]. F. psychrophilum (DSM 3660), environmental Flavobacterium spp. and Chryseobacterium spp. isolates were used as positive and negative controls.

\section{rpoC qPCR design and test of primers}

DNA was extracted using InstaGene kit [Bio-Rad, Hercules (CA), USA]. Partial DNA dependent $\beta^{\prime}$ subunit RNA polymerase $($ rpoC) gene sequences were amplified based on the RNA polymerase $\beta$ ' subunit primers sequences described by Griffiths et al. [49] with the addition of sequence tags UP1s and UP2sr (rpoC_F 5'- GAAGTCATCATGACCGTTCTG CAATHGGNGARCCNGGNACNCA-3' and rpoC_R 5'AGCAGGGTACGGATGTGCGAGCCGGNARNCCNCC NGTDATRTC-3'; synthesized by Microsynth, Switzerland) to increase sequencing performance [50]. The PCR reaction was carried out in a total volume of $50 \mu \mathrm{l}$ using 2.5 U HotStarTaq DNA Polymerase (QIAGEN-Switzerland), $7 \mathrm{mM} \mathrm{MgCl}_{2}$, PCR Buffer 1X (QIAGEN-Switzerland), $0.2 \mathrm{mM}$ dNTP (Roche, Switzerland), $0.2 \mu \mathrm{M}$ of each forward and reverse primer, and $5 \mu$ of InstaGene DNA extract. The thermal cycle started with 15 min HotStarTaq activation at $95^{\circ} \mathrm{C}$ followed by 36 cycles of $1 \mathrm{~min}$ at $94^{\circ} \mathrm{C}$, $90 \mathrm{~s}$ at $55^{\circ} \mathrm{C}, 1 \mathrm{~min}$ at $72^{\circ} \mathrm{C}$ and eventually an elongation cycle of $7 \mathrm{~min}$ at $72^{\circ} \mathrm{C}$.

Sequences (GenBank access numbers JX657163- JX65 7284) obtained from the rpoC gene general PCR were aligned using MEGA4 [51] and screened for a conserved species-specific fragment that would be used to design a set of primers and a TaqMan probe targeting specifically F. psychrophilum. Primers F.psychro_P1F 5'-GAAGATGG AGAAGGTAATTTAGTTGATATT-3', F. psychro_P1R 5'CAAATAACATCTCCTTTTTCTACAACTTGA-3' and a minor groove binder (MGB), and probe F. psychrophilum_probe 5'- AAACGGGTATTC TTCTTGCTACA -3' (Applied Biosystems) labeled with FAM were tested in silico [52] and with BLAST (Basic local alignment search tool [53]). The primers amplified a fragment of $164 \mathrm{bp}$. PCR was carried out in a final volume of $25 \mu \mathrm{l}$ containing 1X Taq PCR Master Mix Kit (QIAGEN, Switzerland), $0.3 \mu \mathrm{M}$ primers F. psychro_P1F and F. psychro_P1R, and $2.5 \mu \mathrm{l}$ of genomic DNA. Conditions for amplification were $94^{\circ} \mathrm{C}$ for $1 \mathrm{~min}$ followed by 35 cycles of $94^{\circ} \mathrm{C}$ for $30 \mathrm{~s}, 56^{\circ} \mathrm{C}$ for $35 \mathrm{~s}$ and $72^{\circ} \mathrm{C}$ for $30 \mathrm{~s}$, with a final elongation cycle of $7 \mathrm{~min}$ at $72^{\circ} \mathrm{C}$.
DNA of F. psychrophilum, Flavobacterium spp. and other bacterial species isolated from soil, water and fish were used to test sensitivity and specificity of the primers. All tested bacteria and their origin are listed in Table 1.

\section{qPCR cycling parameters}

The qPCR was carried out in a final volume of $20 \mu \mathrm{l}$ containing 1× TaqMan Environmental Master Mix v.2.0 (Applied Biosystems), $0.9 \mu \mathrm{M}$ of each primer, $0.2 \mu \mathrm{M}$ of $F$. psychrophilum probe, $1 \mathrm{X}$ of internal control Exo IPC Mix, $1 \times$ of IC DNA (TaqMan Univ. MMix w Exog IntPostC, Applied Biosystems), and $2 \mu \mathrm{l}$ of template DNA. An internal control was added to each reaction to check for PCR inhibitors. The run consisted of two cycles at $50^{\circ} \mathrm{C}$ for $2 \mathrm{~min}$ and $95^{\circ} \mathrm{C}$ for $10 \mathrm{~min}$, followed by 40 cycles at $95^{\circ} \mathrm{C}$ for $15 \mathrm{~s}$ and $60^{\circ} \mathrm{C}$ for $1 \mathrm{~min}$. All assays were carried out in triplicates. Water was used as negative control and series of quantified DNA dilutions as standards.

\section{Preparation of standards}

F. psychrophilum DNA was amplified by PCR with primers F. psychroP1F and F.psychroP1R. The products were purified with PCR clean-up NucleoSpin ${ }^{\oplus}$ ExtractII (Macherey-Nagel, Germany) and quantified with a Nanodrop spectrophotometer (ND1000, Witek, Switzerland). The total amount of DNA measured was divided by $1.797 \times 10^{-7} \mathrm{pg}$ [the weight of one $r p o C$ fragment (164 bp) [54-56]]. The result was an estimate of the number of gene copies in $1 \mu \mathrm{l}$ of purified product. Serial dilutions from $1 \times 10^{7}$ to $1 \times 10^{0}$ copies/ $\mu$ l of amplified DNA were used to calculate the Limit of Detection (LOD) of the qPCR and as quantitative standards for further analyses.

Serial 10-fold dilutions were made starting from $F$. psychrophilum suspensions [Optical Density $\left(\mathrm{OD}_{595}\right) 0.3 \pm$ 0.02] corresponding to $\left(3 \times 10^{9}\right) \pm\left(7 \times 10^{8}\right)$ cells/ml [16] Each suspension was extracted with DNeasy Blood \& Tissue Kit (QIAGEN - Switzerland) and used to determine the quantification limit (QL).

\section{Limit of detection and quantification limit}

Calibration curves were obtained by plotting cycle time $(\mathrm{Ct})$ values against $\log _{10}$ (gene copies number). The coefficients of regressions as well as the $\mathrm{R}^{2}$ values were calculated. The LOD was calculated using a serial dilution from $2 \times 10^{7}$ to $2 \times 10^{0}$ amplified fragments per reaction of $20 \mathrm{~F}$. psychrophilum amplified DNA standards.

Suspensions of $24 \mathrm{~F}$. psychrophilum isolates (serial dilutions from $2 \times 10^{4}$ to $2 \times 10^{-1}$ cells per reaction) were analyzed to determine the QL. Genomic DNA standards from bacteria suspensions were used to check the reliability of the quantification.

qPCR specificity and potential cross-amplifications with other Flavobacterium spp. were checked using dilutions of DNA extracted from F. branchiophilum (concentrations: 
$10^{6}$ and $10^{5}$ cells per reaction), F. columnare, $F$. johnsoniae, F. psychrolimnae, F. fryxellicola, Flavobacterium sp. and Chryseobacterium sp. (concentrations: $10^{7}$ and $10^{6}$ cells per reaction). In addition, diluted DNA samples of $F$. columnare $\left(10^{7}, 10^{4}, 10^{3}, 10^{2}\right.$ cells per reaction) and $F$. branchiophilum $\left(10^{6}, 10^{4}, 10^{3}, 10^{2}\right.$ cells per reaction) were mixed with decreasing concentrations of $F$. psychrophilum DNA (from $10^{6}$ to $10^{3}$ cells per reaction).

\section{Reliability check}

For the results of the qPCR to be reliable, the coefficient of the standards regression had to be in the range $-3.6--3.0$ (Applied Biosystems, manufacturer's instructions for $\mathrm{qPCR})$, the coefficient of variation of quantification within each standard and sample in triplicates $<25 \%$ and the non target control (water) had to show no amplification within the run $[54,57]$.

\section{qPCR of spleen samples}

Spleens of diseased and symptomless rainbow trout and brown trout were gathered during 2011 and 2012 in the Ticino fish farms and treated as described before. Fish were considered healthy when they showed no disease symptoms and, additionally, no signs of infection or extraordinary mortality were reported in the fish farm.

In total 15 rainbow and brown trout spleens were collected and analyzed during 4 outbreaks while 43 spleens from symptomless fish (rainbow and brown trout) were collected in 2 different fish farms showing no sign of infection.

Spleens from symptomless fish were removed, weight calibrates and stored at $-20^{\circ} \mathrm{C}$ until further processing. Mean spleen weight was $0.013 \pm 0.007 \mathrm{~g}$ for rainbow trout and $0.007 \pm 0.002 \mathrm{~g}$ for brown trout.

At the time of the experiments, spleens from healthy fishes were thawed and homogenized in $200 \mu \mathrm{l}$ of sterile water. $100 \mu \mathrm{l}$ of the suspension were spiked with known amounts of $F$. psychrophilum ( $10^{6}$ to $10^{1}$ cells per reaction) to a final volume of $100 \mu \mathrm{l}$ and extracted using DNeasy Blood \& Tissue Kit (QIAGEN). The remaining $100 \mu \mathrm{l}$ were used as controls in FISH and DNA extraction for F. psychrophilum qPCR screening and quantification purpose.

Spleens from diseased fish were used to quantify levels of infection under real-life conditions. They were removed and homogenized in $200 \mu \mathrm{l}$ of sterile water. It was, however, not possible to weight them. $90 \mu \mathrm{l}$ of the spleen homogenates were plated on CAM and incubated at $15^{\circ} \mathrm{C}$ for 5 to 10 days while $10 \mu \mathrm{l}$ were analysed using FISH with the PanFlavo and $F$. psychrophilum probes [16]. DNA was extracted from the remaining $100 \mu \mathrm{l}$.

\section{Statistical analysis}

Primer specificity (SP) and sensitivity (SE) as well as positive and negative predicted values were assessed by standard PCR. The efficiency of qPCR was calculated as
$\mathrm{E}=10^{-1 / \text { slope }}-1$. A linear regression was used to calculate the LOD and the QL at the fifth percentile of all analyzed samples correctly detected (LOD) or quantified (QL) by the technique using SPSS Statistics for Windows, Version 20.0 (IBM Corp., Armonk, NY).

\section{Competing interests}

The authors declare that they have no competing interests.

\section{Authors' contributions}

NS conceived the study, carried out the Taqman quantitative PCR, analyzed the results and drafted the manuscript. OP participated in the design of the study, analyzed the results and helped in writing the manuscript. HS and TW helped to design the study and to draft the manuscript. All authors read and approved the final version.

\section{Acknowledgements}

We are grateful to Dr. Renzo Lucchini for technical advice and to Dr. Cristina Fragoso and Julie Guidotti for critically reading the manuscript.

\section{Author details}

'Laboratory of Applied Microbiology, University of Applied Sciences and Arts of Southern Switzerland, Via Mirasole 22a, 6500 Bellinzona, Switzerland.

${ }^{2}$ Centre for Fish and Wildlife Health, University of Bern, Länggassstrasse 122 3001 Bern, Switzerland. ${ }^{3}$ POLE Pharma Consulting, Breganzona, Switzerland.

Received: 16 May 2013 Accepted: 22 April 2014

Published: 26 April 2014

\section{References}

1. Baker GC, Gaffar S, Cowan DA, Suharto AR: Bacterial community analysis of Indonesian hot springs. FEMS Microbiol Lett 2001, 200(1):103-109.

2. Eiler A, Bertilsson S: Flavobacteria blooms in four eutrophic lakes: linking population dynamics of freshwater bacterioplankton to resource availability. Appl Environ Microbiol 2007, 73(11):3511-3518.

3. Peeters $K$, Willems A: The gyrB gene is a useful phylogenetic marker for exploring the diversity of Flavobacterium strains isolated from terrestrial and aquatic habitats in Antarctica. FEMS Microbiol Lett 2011, 321(2):130-140.

4. Barnes ME, Brown ML: A review of Flavobacterium psychrophilum biology, clinical signs, and Bacterial Cold Water Disease prevention and treatment. Open Fish Sci J 2011, 4:1-9.

5. Bernardet JF, Kerouault B: Phenotypic and genomic studies of "Cytophaga psychrophila" isolated from diseased rainbow trout (Oncorhynchus mykiss) in France. Appl Environ Microbiol 1989, 55(7):1796-1800.

6. Hesami S, Allen KJ, Metcalf D, Ostland VE, Maclnnes JI, Lumsden JS: Phenotypic and genotypic analysis of Flavobacterium psychrophilum isolates from Ontario salmonids with bacterial coldwater disease. Can J Microbiol 2008, 54(8):619-629.

7. Madetoja J, Dalsgaard I, Wiklund T: Occurrence of Flavobacterium psychrophilum in fish-farming environments. Dis Aquat Organ 2002, 52(2):109-118.

8. Valdebenito S, Avendano-Herrera R: Phenotypic, serological and genetic characterization of Flavobacterium psychrophilum strains isolated from salmonids in Chile. J Fish Dis 2009, 32(4):321-333.

9. Wakabayashi H, Huh GJ, Kimura N: Flavobacterium branchiophila sp. nov., a causative agent of Bacterial Gill Disease of freshwater fishes. Int I Syst Bacteriol 1989, 39(3):213-216.

10. Nematollahi A, Decostere A, Pasmans F, Haesebrouck F: Flavobacterium psychrophilum infections in salmonid fish. J Fish Dis 2003, 26(10):563-574

11. Anderson JI, Conroy DA: The pathogenic myxobacteria with special reference to fish diseases. J appl Bact 1969, 32:30-39.

12. Carlson RV, Pacha RE: Procedure for the isolation and enumeration of myxobacteria from aquatic habitats. Appl Microbiol 1968, 16(5):795-796

13. Lehmann J, Mock D, Stürenberg FJ, Bernardet JF: First isolation of Cytophaga psychrophila from a systemic disease in eel and cyprinids. Dis Aquat Organ 1991, 10:217-220.

14. Pacha RE: Characteristics of Cytophaga psychrophila (Borg) isolated during outbreaks of bacterial cold-water disease. Appl Microbio/ 1968, 16(1):97-101

15. Rangdale RE, Richards RE, Alderman DJ: Isolation of Cytophaga psychrophila, causal agent of rainbow trout fry syndrome (RTFS) from 
reproductive fluids and egg surfaces of rainbow trout (Oncorhynchus mykiss). Bull Eur Ass Fish Pathol 1996, 16(2):63.

16. Strepparava N, Wahli T, Segner H, Polli B, Petrini O: Fluorescent in situ Hybridization: a new tool for the direct identification and detection of F. psychrophilum. PLoS One 2012, In Press.

17. Langendijk PS, Schut F, Jansen GJ, Raangs GC, Kamphuis GR, Wilkinson MH, Welling GW: Quantitative fluorescence in situ hybridization of Bifidobacterium spp. with genus-specific 16S rRNA-targeted probes and its application in fecal samples. Appl Environ Microbiol 1995, 61(8):3069-3075.

18. Madetoja J, Wiklund T: Detection of the fish pathogen Flavobacterium psychrophilum in water from fish farms. Syst Appl Microbiol 2002, 25(2):259-266.

19. Wiklund T, Madsen L, Bruun MS, Dalsgaard I: Detection of Flavobacterium psychrophilum from fish tissue and water samples by PCR amplification. J Appl Microbiol 2000, 88(2):299-307.

20. Altinok I, Capkin E, Kayis S: Development of multiplex PCR assay for simultaneous detection of five bacterial fish pathogens. Vet Microbiol 2008, 131(3-4):332-338.

21. Del Cerro A, Marquez I, Guijarro JA: Simultaneous detection of Aeromonas salmonicida, Flavobacterium psychrophilum, and Yersinia ruckeri, three major fish pathogens, by multiplex PCR. Appl Environ Microbiol 2002 68(10):5177-5180.

22. Carelli G, Decaro N, Lorusso A, Elia G, Lorusso E, Mari V, Ceci L, Buonavoglia C: Detection and quantification of Anaplasma marginale DNA in blood samples of cattle by real-time PCR. Vet Microbio/ 2007, 124(1-2):107-114

23. Lewin SR, Vesanen $M$, Kostrikis L, Hurley A, Duran M, Zhang L, Ho DD, Markowitz M: Use of real-time PCR and molecular beacons to detect virus replication in human immunodeficiency virus type 1-infected individuals on prolonged effective antiretroviral therapy. J Virol 1999, 73(7):6099-6103.

24. Trombley AR, Wachter L, Garrison J, Buckley-Beason VA, Jahrling J, Hensley LE, Schoepp RJ, Norwood DA, Goba A, Fair JN, Kulesh DA: Comprehensive panel of real-time TaqMan polymerase chain reaction assays for detection and absolute quantification of filoviruses, arenaviruses, and New World hantaviruses. Am J Trop Med Hyg 2010, 82(5):954-960

25. Marancik DP, Wiens GD: A real-time polymerase chain reaction assay for identification and quantification of Flavobacterium psychrophilum and application to disease resistance studies in selectively bred rainbow trout Oncorhynchus mykiss. FEMS Microbiol Lett 2013, 339(2):122-129.

26. Orieux N, Bourdineaud JP, Douet DG, Daniel P, Le Henaff M: Quantification of Flavobacterium psychrophilum in rainbow trout, Oncorhynchus mykiss (Walbaum), tissues by qPCR. J Fish Dis 2011, 34(11):811-821.

27. Chelo IM, Ze-Ze L, Tenreiro R: Congruence of evolutionary relationships inside the Leuconostoc-Oenococcus-Weissella clade assessed by phylogenetic analysis of the $16 \mathrm{~S}$ rRNA gene, dnaA, gyrB, rpoC and dnaK. Int J Syst Evol Microbiol 2007, 57(Pt 2):276-286.

28. Mittenhuber $\mathrm{G}$ : Comparative genomics and evolution of genes encoding bacterial (p)ppGpp synthetases/hydrolases (the Rel, RelA and SpoT proteins). J Mol Microbiol Biotechnol 2001, 3(4):585-600.

29. Morse R, Collins MD, O'Hanlon K, Wallbanks S, Richardson PT: Analysis of the beta' subunit of DNA-dependent RNA polymerase does not support the hypothesis inferred from $16 \mathrm{~S}$ rRNA analysis that Oenococcus oen (formerly Leuconostoc oenos) is a tachytelic (fast-evolving) bacterium. Int J Syst Bacterio/ 1996, 46(4):1004-1009.

30. Duchaud E, Boussaha M, Loux V, Bernardet JF, Michel C, Kerouault B, Mondot S, Nicolas P, Bossy R, Caron C, Bessieres P, Gibrat JF, Claverol S, Dumetz F, Le Henaff M, Benmansour A: Complete genome sequence of the fish pathogen Flavobacterium psychrophilum. Nat Biotechnol 2007, 25(7):763-769

31. Morillo JM, Lau L, Sanz M, Herrera D, Silva A: Quantitative real-time PCR based on single copy gene sequence for detection of Actinobacillus actinomycetemcomitans and Porphyromonas gingivalis. $J$ Periodontal Res 2003, 38(5):518-524

32. Bustin SA, Benes V, Garson JA, Hellemans J, Huggett J, Kubista M, Mueller R Nolan T, Pfaffl MW, Shipley GL, Vandesompele J, Wittwer CT: The MIQE guidelines: minimum information for publication of quantitative real-time PCR experiments. Clin Chem 2009, 55(4):611-622.

33. Barbier P, Houel A, Loux V, Poulain J, Bernardet JF, Touchon M, Duchaud E: Complete genome sequence of Flavobacterium indicum GPSTA100-9T, isolated from warm spring water. J Bacteriol 2012, 194(11):3024-3025,

34. McBride MJ, Xie G, Martens EC, Lapidus A, Henrissat B, Rhodes RG, Goltsman E, Wang W, Xu J, Hunnicutt DW, Staroscik AM, Hoover TR, Cheng YO, Stein JL:
Novel features of the polysaccharide-digesting gliding bacterium Flavobacterium johnsoniae as revealed by genome sequence analysis. Appl Environ Microbiol 2009, 75(21):6864-6875.

35. Tekedar HC, Karsi A, Gillaspy AF, Dyer DW, Benton NR, Zaitshik J, Vamenta S, Banes MM, Gulsoy N, Aboko-Cole M, Waldbieser GC, Lawrence ML: Genome sequence of the fish pathogen Flavobacterium columnare ATCC 49512. J Bacteriol 2012, 194(10):2763-2764.

36. Touchon M, Barbier P, Bernardet JF, Loux V, Vacherie B, Barbe V, Rocha EP, Duchaud E: Complete genome sequence of the fish pathogen Flavobacterium branchiophilum. Appl Environ Microbiol 2011, 77(21):7656-7662

37. Nematollahi A, Decostere A, Pasmans F, Ducatelle R, Haesebrouck F: Adhesion of high and low virulence Flavobacterium psychrophilum strains to isolated gill arches of rainbow trout Oncorhynchus mykiss. Dis Aquat Organ 2003, 55(2):101-107.

38. Brown LL, Cox WT, Levine PL: Evidence that the causal agent of bacteria cold-water disease Flavobacterium psychrophilum is transmittes within salmonid eggs. Dis Aquat Organ 1997, 29:213-218.

39. McCormick A, Loeffler J, Ebel F: Aspergillus fumigatus: contours of an opportunistic human pathogen. Cell Microbiol 2010, 12(11):1535-1543.

40. Miceli MH, Diaz JA, Lee SA: Emerging opportunistic yeast infections. Lancet Infect Dis 2011, 11(2):142-151.

41. Morgan AL, Thompson KD, Auchinachie NA, Migaud H: The effect of seasonality on normal haematological and innate immune parameters of rainbow trout Oncorhynchus mykiss L. Fish Shellfish Immunol 2008, 25(6):791-799

42. Banks JL: Raceway density and water flow as factors affecting spring chinook salmon (Oncorhynchus tshawytscha) during rearing and after release. Aquaculture 1994, 119(2-3):201-217.

43. Karvonen A, Rintamaki P, Jokela J, Valtonen ET: Increasing water temperature and disease risks in aquatic systems: climate change increases the risk of some, but not all, diseases. Int J Parasitol 2010, 40(13):1483-1488.

44. Pulkkinen $K$, Suomalainen $L R$, Read AF, Ebert D, Rintamaki P, Valtonen ET: Intensive fish farming and the evolution of pathogen virulence: the case of columnaris disease in Finland. Proc Biol Sci 2010, 277(1681):593-600.

45. Suomalainen $L R$, Tiirola MA, Valtonen ET: Influence of rearing conditions on Flavobacterium columnare infection of rainbow trout, Oncorhynchus mykiss (Walbaum). J Fish Dis 2005, 28(5):271-277.

46. Lorenzen E, Olesen NJ: Characterization of isolates of Flavobacterium psychrophilum associated with coldwater disease or rainbow trout fry syndrome II: serological studies. Dis Aquat Organ 1997, 31:209-220

47. Green DM, Gregory A, Munro LA: Small- and large-scale network structure of live fish movements in Scotland. Prev Vet Med 2009, 91(2-4):261-269.

48. Tonolla M, Peduzzi S, Hahn D, Peduzzi R: Spatio-temporal distribution of phototrophic sulfur bacteria in the chemocline of meromictic Lake Cadagno (Switzerland). FEMS Microbiol Ecol 2003, 43(1):89-98.

49. Griffiths E, Gupta RS: Signature sequences in diverse proteins provide evidence for the late divergence of the Order Aquificales. Int Microbiol 2004, 7(1):41-52.

50. Yamamoto S, Harayama S: PCR amplification and direct sequencing of gyrB genes with universal primers and their application to the detection and taxonomic analysis of Pseudomonas putida strains. Appl Environ Microbiol 1995, 61(10):3768

51. Tamura K, Dudley J, Nei M, Kumar S: MEGA4: molecular evolutionary genetics analysis (MEGA) software version 4.0. Mol Biol Evol 2007, 24(8):1596-1599.

52. Bikandi J, San Millan R, Rementeria A, Garaizar J: In silico analysis of complete bacterial genomes: PCR, AFLP-PCR and endonuclease restriction. Bioinformatics 2004, 20(5):798-799.

53. Altschul SF, Gish W, Miller W, Myers EW, Lipman DJ: Basic local alignment search tool. J Mol Biol 1990, 215(3):403-410.

54. Hellemans J, Mortier G, De Paepe A, Speleman F, Vandesompele J: qBase relative quantification framework and software for management and automated analysis of real-time quantitative PCR data. Genome Biol 2007, 8(2):R19.

55. Mackay IM: Real-time PCR in the microbiology laboratory. Clin Microbiol Infect 2004, 10(3):190-212.

56. Yun JJ, Heisler LE, Hwang II, Wilkins O, Lau SK, Hyrcza M, Jayabalasingham B, Jin J, McLaurin J, Tsao MS, Der SD: Genomic DNA functions as a universal 
external standard in quantitative real-time PCR. Nucleic Acids Res 2006, 34(12):e85.

57. Joly P, Falconnet PA, Andre J, Weill N, Reyrolle M, Vandenesch F, Maurin M, Etienne J, Jarraud S: Quantitative real-time Legionella PCR for environmental water samples: data interpretation. Appl Environ Microbiol 2006, 72(4):2801-2808

doi:10.1186/1471-2180-14-105

Cite this article as: Strepparava et al:: Detection and quantification of Flavobacterium psychrophilum in water and fish tissue samples by quantitative real time PCR. BMC Microbiology 2014 14:105.

\section{Submit your next manuscript to BioMed Central} and take full advantage of:

- Convenient online submission

- Thorough peer review

- No space constraints or color figure charges

- Immediate publication on acceptance

- Inclusion in PubMed, CAS, Scopus and Google Scholar

- Research which is freely available for redistribution 